Articles accepted for publication in

\title{
Journal for the History of Astronomy
}

include

The First Phases of the Theorica Planetarum Printed Tradition Isabelle Pantin

The Pin-and-Slot Device of the Antikythera Mechanism Christián C. Carmen, Alan Thorndike and James Evans

Science Rather than God: Riccioli's Review of the Case for and against the Copernican Hypothesis

Christopher M. Graney

The Geometrical Diagrams in Regiomontanus's Disputationes Michael H. Shank

Michael Maestlin's Mystery Gerd Grasshoff

The Eccentricity of the Sun: Kepler's Novel Method of Calculation Yaakov Zik and Giora Hon

Messier's Missed Discovery of Pallas in April 1779

René Bourtembourg

The Third Edition of Copernicus's De Revolutionibus

Djoeke van Netten

The Crossover of the Sun and the Moon

Fabio Silva and Fernando Pimenta

Journal for the History of Astronomy was founded in 1970. The 2012 subscription to $J H A$, four issues post paid, is $\$ 300$ (online and print) in the Americas and Japan, $£ 150$ elsewhere (\$98 or $£ 49$, print only, direct to private subscribers).

SCIENCE History Publications LtD

16 Rutherford Road, Cambridge, CB2 8HH, England tel. +44 (0)1638-605464; fax. +44 (0)1638-605465

www.shpltd.co.uk; e-mail: journals@ shpltd.co.uk 


\section{THE BRITISH SOCIETY FOR THE HISTORY OF SGIENGE}

Membership of the Society, which includes a subscription to The British Fournal for the History of Science, is open to all persons approved by the Council of the Society and elected at an ordinary meeting. The annual subscription for the membership year 2012 is $£ 41.00$ (\$66.00) or $£ 22.00$ (\$54.00 or $€ 32)$ for associate membership, which includes students at centres of higher education. There is an Introductory Offer for ordinary members who pay $£ 33.00(£ 66.00)$ for the first year. Applications for membership should be made on a form available from the Society's Executive Secretary at the address below. Payment may be made by cheque or credit card.

The British Journal for the History of Science is the official organ of the Society. All correspondence on the contents of the Journal should be addressed to the Editor, Jon Agar, Department of Science and Technology Studies, University College London, London WC1E 6BT, email ucrhjea@ucl.ac.uk

Book reviews: Books for review should be sent to the Reviews Editor, Dr Adam Mosley, School of Arts and Humanities: History and Classics, Swansea University, Singleton Park, Swansea, SA2 8PP, Wales, United Kingdom.

BSHS publications: BSHS Monograph Series is designed to allow the publication of monographic studies in the history of science quickly and cheaply. All correspondence on the subject of monographs should be sent to Lucy Tetlow, Executive Secretary, PO Box 3401, Norwich NR7 7JF. Twelve monographs are currently available.

Recent titles are as follows:

Images of the Earth: Essays in the History of the Environmental Sciences. Edited by L. J. Jordanova and R. Porter. Second edition. 1997. £17.

Science in Art: Works in the National Gallery that illustrate the History of Science and Technology. By J. V. Field and F. A. J. L. James. 1997. £15.

To See the Fellows Fight: Eye-witness accounts of meetings of the Geological Society of London and its Club, 1822-1868. By J. C.Thackray. 2003. £15.

The Society's newsletter, Viewpoint, an informal publication, appears three times a year. It is free to members, $£ 10.00$ $(20.00)$ for institutions and non-members from the Executive Secretary.

Administrative business of the Society is handled by Lucy Tetlow, Executive Secretary, British Society for the History of Science, PO Box 3401, Norwich, NR7 7JF. The Society is registered in England as a Limited Company (No. 562208) and is a Registered Charity (No. 258854). Telephone and Fax (44) (0) 1252 641135. Email lucy.tetlow@bshs.org.uk.

Information about the Society is available through the Internet: http://www.bshs.org.uk

Copying: This journal is registered with the Copyright Clearance Center, 222 Rosewood Drive, Danvers, MA 09123. Organizations in the USA who are also registered with the CGC may therefore copy material (beyond the limits permitted by sections 107 and 108 of US copyright law) subject to payment to CCC of the per-copy fee of $\$ 12.00$. This consent does not extend to multiple copying for promotional or commercial purposes. Code 0007-0874/2012 $\$ 12.00$.

ISI Tear Sheet Service, 3501 Market Street, Philadelphia, Pennsylvania 19104, USA, is authorized to supply single copies of separate articles for private use only.

Organizations authorized by the Copyright Licensing Agency may also copy material subject to the usual conditions. Articles from the Journal in electronic or microfiche form can be obtained from Cambridge Journals Online (www.journals.cambridge.org), Proquest (www.proquest.com) and NAPC (www.napubco.com).

For all other use, permission should be sought from Cambridge University Press or from its American branch.

Advertising: Contact the Journals Advertising Manager, Cambridge University Press, University Printing House, Shaftesbury Road, Cambridge CB2 8BS.

Back volumes are obtainable as follows: Volumes 1-23: BSHS Executive Secretary, PO Box 3401, Norwich, NR7 7JF, UK. For Volume 24 onwards, apply to Cambridge University Press in printed form.

Information on the British Fournal for the History of Science and all other Cambridge journals can be accessed via www.journals.cambridge.org

Claims for missing issues should be made immediately on receipt of the subsequent issue.

This journal issue has been printed on FSC-certified paper and cover board. FSC is an independent, non-governmental, not-for-profit organization established to promote the responsible management of the world's forests. Please see www.fsc.org for information.

Printed in the United Kingdom at the University Press, Cambridge 


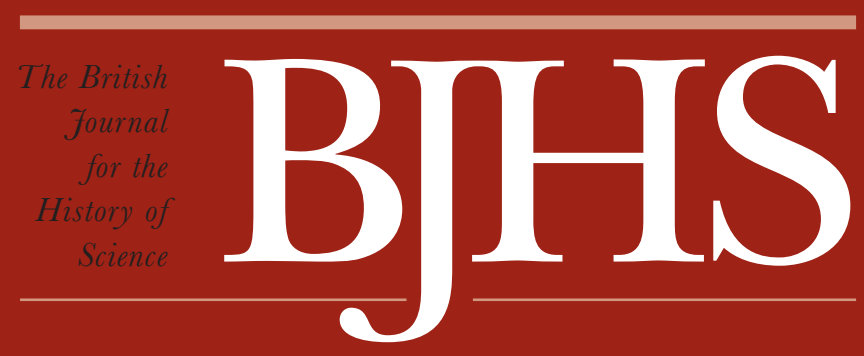

Volume 4.5

Part 1 No. $164 \quad$ March 2012

1 The Ivory Tower: the history of a figure of speech and its cultural uses

STEVEN SHAPIN

29 Charles Darwin's use of theology in the Origin of Species STEPHEN DILLEY

57 By design: James Clerk Maxwell and the evangelical unification of science MATTHEW STANLEY

75 Preaching at the British Association for the Advancement of Science: sermons, secularization and the rhetoric of conflict in the 1870 s CIARAN TOAL

97 The limits to 'spin-off': UK defence R \& D and the development of gallium arsenide technology

GRAHAM SPINARDI

123 Book reviews

149 Books received

\section{B S H S \\ THE BRITISH \\ SOCIETY FOR \\ THE HISTORY \\ OF SCIENCE}

Published for The British Society for the History of Science

by Cambridge University Press

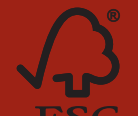

FSC

Fwwitscor or
MIX

Paper from responsible sources $\mathrm{FSC}^{\circ} \mathrm{C} 018127$
CAMBRIDGE UNIVERSITY PRESS 